\title{
Scripture and Toleration between Reformation and Enlightenment ${ }^{*}$
}

\author{
Professor John Coffey (University of Leicester) \\ Published in Eliane Glaser, ed., Religious Tolerance in the Atlantic World: Early Modern \\ and Contemporary Perspectives (Palgrave, 2014), 14-40.
}

That recent years have witnessed a resurgence of historical scholarship on religious toleration is hardly surprising. Rarely has the subject seemed so relevant or so pressing. Of course, earlier historians were equally convinced that it mattered in their own time. W.K. Jordan published his four volume history of The Development of Toleration in England under the growing shadow of fascism in the 1930s, and it was designed as an apologia for fragile liberal values. ${ }^{1}$ The Jesuit Joseph Lecler's great work, Histoire de la Tolérance au Siècle de la Réforme (1955) appeared in the midst of Catholic debates over church-state relations that culminated in Vatican II's landmark Declaration on Religious Freedom. ${ }^{2}$ But twenty-first century anxieties over religion and politics have injected a new sense of urgency into what might otherwise be a quiet backwater of historical enquiry. While the clash between Islamic militants and the West has caused many to revisit the Crusades and the history of MuslimChristian interaction, public intellectuals have been equally inclined to turn to the early modern era. This is perhaps most marked in the United States, where controversies over church and state are routinely rooted in the eighteenth century. Here the Religious Right fights the secular Left over the Founding Fathers as Protestants and Catholics once fought over Augustine. As Gordon Wood remarked, the Founders have become America's church fathers. ${ }^{3}$ But we find the retrospective turn in Europe too. Salman Rushdie once pronounced that the problem with Islam was that it had never had a Reformation; he later corrected himself. What Islam needs, he explained, is 'not so much a reformation... as an Enlightenment'. Either way, he recommended a recapitulation of Europe's early modern learning experience. ${ }^{4}$

\footnotetext{
*An earlier version of this paper was presented at the symposium on 'Religion, Toleration and Coexistence' organised by the Humanities Institute at University College Dublin. I am grateful to Marc Caball and to the participants for their comments. For helpful feedback on a later draft, I wish to thank Richard Bonney and Eliane Glaser.

${ }^{1}$ Wilbur K. Jordan, The Development of Religious Toleration in England, 4 vols (Cambridge, MA: Harvard University Press, 1932-40).

${ }^{2}$ The English translation appeared five years later: Joseph Lecler, S.J., Toleration and the Reformation, trans. T.L. Westow, 2 vols (London: Longmans, 1960). For the intra-Catholic debate on religious freedom in which Lecler participated see Philippe Denis and Jean-Pierre Massaut, 'Le Père Lecler, la Tolerance et le Concile', Recherches de Science Religieuse, 78 (1990), 15-39; Joseph Komonchak, 'Religious Freedom and the Confessional State: The Twentieth-Century Discussion', Revue d'Histoire Ecclesiastique, 95 (2000), 634-50; Emile Perreau-Saussine, Catholicism and Democracy: An Essay in the History of Political Thought, trans. Richard Rex (Princeton: Princeton University Press, 2012), pp. 127-131.

${ }^{3}$ Gordon Wood, 'Rambunctious American Democracy', New York Review of Books, 9 May 2002, p. 21.

${ }^{4}$ Salman Rushdie, 'Muslims unite! A new Reformation will bring your faith into the modern era', The Times, 11 August 2005; 'Lesson one for the modern Muslim: remember, this is not the $8^{\text {th }}$ century', The Times, 12 September 2005. Rushdie's articles generated widespread debate and online searches will reveal numerous articles discussing whether Islam needs a Reformation or an Enlightenment. The idea of 'an Islamic
} 
In the wake of 9/11, various historians have joined the on-going debate, keen to demonstrate that early modern history has something valuable to teach us. For sheer ambition, none compares to Jonathan Israel. His 3000-page trilogy on the radical Enlightenment and its foes, is an intervention in contemporary debates about religion and politics, and pits the (allegedly) liberal democratic secularism of Spinoza against the evils of fundamentalism and traditionalism, the spinelessness of postmodernism and multiculturalism. ${ }^{5}$ Another tract for the times (albeit a good deal briefer) is Perez Zagorin's, How the Idea of Toleration Came to the West (2003). He argues that 'the modern concepts of religious toleration and freedom' are 'the offspring of Western civilisation', and traces their emergence in the writings of radical Protestants like Castellio, Milton and Locke. His book concludes with the wish that these ideals would be embraced where they do not exist today - 'including considerable parts of the Islamic world and the few remaining communist countries' . ${ }^{6}$ Benjamin Kaplan's Divided by Faith (2007) sets out to undercut the kind of grand narratives told by Zagorin and Israel, Whiggish constructs centred on the liberating feats of progressive intellectuals. But he too has no doubt about what he called the 'immediacy and relevance' of early modern European history. Modern Europeans are now asking themselves the same question as their ancestors: 'Can people whose basic beliefs are irreconcilably opposed live together peacefully?' The early modern answer, suggests Kaplan, was (often, surprisingly) yes. There were 'viable alternatives to bloodshed'. And they were worked out not by grand theorists but by local magistrates and everyday folk who devised various means of coexistence. From this fact, Kaplan draws a moral lesson. The practice of toleration does not depend on other cultures accepting the West's post-Enlightenment secular values - it can develop within deeply traditional religious cultures. ${ }^{7}$

By constructing different narratives about religion, toleration and coexistence, these historians have offered alternative approaches to the challenge of militant religion, and especially resurgent Islam. For Israel, the solution is radical Enlightenment secularism. For Zagorin, it is the moderate Enlightenment value of toleration that emerged from within the Western Christian tradition thanks to its bolder spirits. For Kaplan, our best hope lies in practical, piecemeal practices of accommodation - regimes of toleration that may well look quite different from one culture to another.

James Simpson tells another kind of story about religion and intolerance in his much discussed work, Burning to Read: English Fundamentalism and its Reformation Opponents.

\footnotetext{
Reformation' predates 2005. See for example Abdullahi Ahmed An-Na 'im, Toward an Islamic Reformation: Civil Liberties, Human Rights and International Law (Syracuse University Press, 1996); Michelle Browers and Charles Kurzman (eds), An Islamic Reformation? (Lexington Books, 2004). The notion of 'an Islamic Enlightenment' appears to have gained traction more recently. See M. Hakan Yavuz, Toward an Islamic Enlightenment: The Gulen Movement (New York: Oxford University Press, 2012).

5 Jonathan Israel, Radical Enlightenment (Oxford: Oxford University Press, 2001); Enlightenment Contested (Oxford: Oxford University Press, 2006); Democratic Enlightenment (Oxford: Oxford University Press, 2011). ${ }^{6}$ Perez Zagorin How the Idea of Toleration Came to the West (Princeton: Princeton University Press, 2003), xii, p. 311.

${ }^{7}$ Benjamin Kaplan, Divided by Faith: Religious Conflict and the Practice of Toleration in Early Modern Europe (Cambridge, MA: Harvard University Press, 2007), pp. 12, 357-58.
} 
It displays the same sense of urgency that we see in Israel, Zagorin and Kaplan. He writes against a political context in which 'fundamentalist reading practices' are driving the legislative programme of the Religious Right and the militancy of Islamic terrorism. 'Reading and its consequences', he warns, 'are once again becoming capable of violently changing the world'. Burning to Read traces the problem (at least within Christianity) to the harsh literalism ushered in by the Reformation. And he takes aim at the celebration of the Protestant Bible that one finds in scholars like David Daniell (or broadcasters like Melvyn Bragg), who see Reformation biblicism as a liberating and democratic development. For Simpson, this Whiggish complacency ignores the dark side of Protestant literalism.

Reformation styles of Bible reading, he alleges, produced nearly 'Two Hundred Years of Biblical Violence' in western Europe. Much of this violence was psychological (such as the fear of damnation wrought by reading about predestination). But sometimes, it was physical, as when Calvinists re-enacted the iconoclastic purges of Israel's godly kings. ${ }^{8}$

\section{Scripture and Toleration}

In this paper, I want to pick up Simpson's themes of biblical interpretation and 'biblical violence'. In particular, I will explore the scriptural reasoning of seventeenth-century tolerationists, who sought to neutralise the 'texts of terror' used to justify religious persecution. ${ }^{9}$ And I will argue that the post-Reformation toleration controversy was a textual affair. From Castellio to Bayle, tolerationists were preoccupied by the challenge of biblical hermeneutics.

Until the recent surge of interest in Christian Hebraism and the reception history of the Bible, this topic received little systematic attention. ${ }^{10}$ For the most part, scholars concentrated on arguments that were deemed 'relevant' in a secular age. Students of Locke's Letters concerning Toleration, for example, devoted exhaustive analysis to his philosophical arguments, but largely bypassed his biblical hermeneutics. ${ }^{11}$ Even John Marshall's magnum opus on John Locke, Toleration and Early Enlightenment Culture, devoted a number of

\footnotetext{
8 James Simpson, Burning to Read: English Fundamentalism and its Reformation Opponents (Cambridge, MA: Harvard University Press, 2007), pp. 8, 10-14, passim.

${ }^{9}$ I take the phrase from Phyllis Trible, Texts of Terror: Literary-Feminist Readings of Biblical Narrative (Philadelphia: Fortress Press, 1984). 'Scriptural reasoning' is the name given to the practice of reading each other's scriptures in small interfaith groups: http://www.scripturalreasoning.org/ (accessed 4 October 2012).

${ }^{10}$ These trends can be explored respectively through the journal Hebraic Political Studies (2005-) and Michael Lieb, Emma Mason and Jonathan Roberts (eds), The Oxford Handbook of the Reception History of the Bible (Oxford: Oxford University Press, 2011).

${ }^{11}$ See for example the two studies of the Locke-Proast controversy: Richard Vernon, The Career of Toleration: John Locke, Jonas Proast and After (Montreal: McGill University Press, 1997); Adam Wolfson, Persecution or Toleration: An Explication of the Locke-Proast Quarrel, 1689-1704 (Lanham MD: Lexington Books, 2010). Of course, scriptural reasoning was much less prominent in these exchanges than in the IndependentPresbyterian debates of the 1640 s, but neither book does justice to Locke's Hebraic and dispensational arguments.
} 
chapters to expounding the main lines of argument used by tolerationists, but largely bypassed their engagement with the Bible. ${ }^{12}$

This neglect of the scriptural dimension is problematic, for several reasons. In the first place, it is a-historical. It ignores a prominent strand in Locke's texts, and in many other tolerationist works. To marginalise it because it seems irrelevant in the modern age is to distort the text, misrepresent the past and prematurely secularise our subjects. ${ }^{13}$ Second, when scholars ignore the biblical, they forget that the Christian doctrine of religious coercion was scripturally constructed (and so had to be scripturally deconstructed). It was erected by St Augustine in the early fifth century, in seminal letters justifying the repression of the Donatists. And while Augustine advanced abstract theological or philosophical arguments, his case drew heavily on biblical materials. Most famously, he appealed to Christ's Parable of the Great Banquet, in which the host commands his servants to go into the highways and byways to find guests, declaring 'compelle intrare'. ${ }^{14}$

Finally, glossing over scriptural argument is intellectually parochial and misses a feature of these debates that is becoming more rather than less relevant. As the philosopher John Gray puts it (in characteristically provocative fashion):

The return of religion as a pivotal factor in politics and war is one of the defining features of the age, and it is time Paine, Marx and other secular prophets were gently shelved in the stacks. The writings of these Enlightenment savants have stirred events for a very brief period in history, now clearly coming to an end....But the books that have most formed the past, and which are sure also to shape the future, are the central texts of the world religions. ${ }^{15}$

Gray's prophecy about the shelf-life of secular Enlightenment classics may well prove false, but his point about the persistent power and appeal of scriptural texts remains. The Bible and the Qu'ran are read as intensively as ever; and more extensively than ever before. Across the global South, we see the emergence of what Philip Jenkins calls 'new Christendoms', where the Bible is read devoutly and often taken literally. The problem of violence in sacred texts has taken on a new significance. ${ }^{16}$ Given this contemporary context, the scriptural dimension of the early modern toleration controversy merits renewed attention. Indeed, as we shall see, there are striking parallels between the current intra-Islamic debate over apostasy, a debate which turns on the interpretation of the Koran and the hadith and the post-Reformation dispute over religious coercion.

\footnotetext{
12 John Marshall, John Locke, Toleration and Early Enlightenment Culture (Cambridge: Cambridge University Press, 2006), pp. 536-679.

${ }^{13}$ See John Coffey, 'Quentin Skinner and the religious dimension of early modern political thought', in Alister Chapman, John Coffey and Brad Gregory (eds), Seeing Things their Way: Intellectual History and the Return of Religion (University of Notre Dame Press, 2009), ch. 3.

${ }^{14}$ The Political Writings of St Augustine, ed. H. Paolucci (Chicago: 1962), pp. 184-240.

${ }^{15}$ John Gray, 'Battle of the books', New Statesman, 31 July 2006.

${ }^{16}$ Philip Jenkins, The Next Christendom: The Coming of Global Christianity, third edition (New York: Oxford University Press, 2011); The New Faces of Christianity: Believing the Bible in the Global South (New York: Oxford University Press, 2008); Laying Down the Sword: Why we Can't Ignore the Bible's Violent Verses (New York: HarperCollins, 2011).
} 


\section{The Robinson Circle and the Furly Circle}

In exploring this particular battle for the Bible, I want to focus on two influential coteries of Protestant tolerationists, one based in London in the 1640s, the other centred on Rotterdam in the 1680s. The first group included the poet and pamphleteer, John Milton. Recent analysis by David Adams suggests that Milton's Areopagitica was printed on a press owned by Henry Robinson, a London merchant who was part of the intellectual circle of Samuel Hartlib. The press also published pro-toleration works by the future Leveller leader, William Walwyn, and the founder of Rhode Island, Roger Williams. ${ }^{17}$ Certainly, these figures belonged to a network of London-based radical Independents that agitated for far-reaching religious toleration. ${ }^{18}$ Four decades later, another tolerationist grouping was hosted in Rotterdam by the Quaker Benjamin Furly. His personal library contained over four thousand books, including a remarkable range of early tolerationist works, among them Williams’ Bloudy Tenent of Persecution and its sequel The Bloudy Tenent Yet More Bloudy, and Milton's Treatise of Civil Power. ${ }^{19}$ Among Furly's conversation partners were the English philosopher John Locke, the Huguenot scholar Pierre Bayle, and the Arminian divine, Philip van Limborch. According to John Marshall, these figures were 'at the epicentre of the early Enlightenment'. ${ }^{20}$

Each of these groups was deeply preoccupied by the problem of Scripture and toleration. That may seem surprising, for to turn from Robinson's circle in the 1640s to Furly's circle in the 1680s is to turn from the world of the Puritan Revolution to the era of the early Enlightenment. It is tempting to draw a sharp contrast between Puritan biblicists and Enlightenment rationalists. Yet Locke and van Limborch were absorbed in questions of biblical exegesis. As a professor of theology at the Remonstrant seminary, van Limborch naturally cited Scripture copiously in his systematic theology. ${ }^{21}$ For his part, Locke was as much a lay theologian as Milton. He wrote a paraphrase of Paul's epistles, and engaged in intensive exegesis in both The Reasonableness of Christianity and the First Treatise of Government. $^{22}$ In one manuscript, he listed 21 biblical passages that could be used to teach

\footnotetext{
${ }^{17}$ David Adams, 'The printing and publishing history of Milton's Areopagitica', unpublished paper. I am grateful to the author for allowing me to see this paper.

${ }^{18}$ I have explored this milieu in John Goodwin and the Puritan Revolution (Woodbridge: Boydell and Brewer, 2006), chs. 4-6.

${ }^{19}$ See Bibliotheca Furliana (1714), pp. 62, 89, 180.

${ }^{20}$ Marshall, John Locke, p. 493.

${ }^{21}$ Philip van Limborch, Theologia Christiana (Amsterdam, 1686, 1700), translated by William Jones as $A$ Compleat System, or Body of Divinity (London, 1702).

${ }^{22}$ See John Locke, The Reasonableness of Christianity, ed. J.C. Higgins-Biddle (Oxford, 1999), Appendix II: Index of Biblical References (pp. 220-26). On biblical reasoning in Locke's political thought see Jeremy Waldron, God, Locke and Equality (Cambridge: Cambridge University Press, 2002).
} 
toleration. ${ }^{23}$ As for Bayle, his Philosophical Commentary was devoted to countering Augustine's literalist reading of ces Paroles de Jésus-Christ, "Contrain-les d'Entrer". ${ }^{24}$.

With hindsight, historians have suggested that Europeans were on the cusp of a new intellectual era, and witnessing a major crisis of scriptural authority. And we do indeed see the origins of modern biblical criticism in the writings of Hobbes, Spinoza and Richard Simon. ${ }^{25}$ But contemporaries living through the 1680 s were hardly conscious of entering an age of Enlightenment. As John Marshall has vividly demonstrated, this was 'one of the most religiously repressive decades in European history', epitomised by the Revocation of the Edict of Nantes. ${ }^{26}$ If Milton had to worry about Parliament's Blasphemy Act in 1648 and the coercive schemes of Presbyterians and Anglicans, Locke and van Limborch lived to see the persecution of French Huguenots, Italian Waldensians and English Dissenters, the Scottish and English Blasphemy Acts of 1695 and 1697, and the execution of the freethinking Edinburgh student, Thomas Aikenhead. ${ }^{27}$

Moreover, during both periods, the practice of religious coercion was underpinned by a scriptural rationale. ${ }^{28}$ Seventeenth-century political thinkers were immersed in the Old Testament, and defenders of religious uniformity leant especially heavily on Hebrew Scripture. Not for nothing has Eric Nelson dubbed this 'the Biblical Century' in the history of political thought. ${ }^{29}$ Roger Williams explained that he would give careful consideration to the case of ancient Israel because 'so great a waeight [sic] of this controversie lyes upon this president of the Old Testament' 30 'The Inquisitors of these days', noted Henry Robinson, 'have no better ground for their strict proceedings, then the Old Testament which expressly commanded Idolatry to be rooted out'. ${ }^{31}$ Milton concurred that 'the main plea' of the wouldbe forcers of conscience was to the example of 'the kings of Judah', who 'used force in

\footnotetext{
${ }^{23}$ Bodleian Library, MS Locke c33, 24v. The religious character of Locke's case for toleration is underlined by Jack Turner, 'John Locke, Christian Mission, and Colonial America', Modern Intellectual History, 8 (2011), $267-$ 97.

${ }^{24}$ Pierre Bayle, Commentaire Philosophique sur ces Paroles de Jésus-Christ, "Contrain-les d'Entrer" (1686-87). I will cite from the contemporary English translation, A Philosophical Commentary on These Words of the Gospel, Luke 14:23, "Compel them to Come In, That My House May be Full" (1708), edited and with an introduction by John Kilcullen and Chandran Kukathas (Indianapolis: Liberty Fund, 2005).

${ }^{25}$ J. Samuel Preus, Spinoza and the Irrelevance of Biblical Authority (Cambridge: Cambridge University Press, 2001); Noel Malcolm, 'Hobbes, Ezra and the Bible: The History of a Subversive Idea', in his Aspects of Hobbes (Oxford: Oxford University Press, 2004), ch. 12; David Katz, God's Last Words: Reading the English Bible from the Reformation to Fundamentalism (Oxford: Oxford University Press, 2004), pp. 70-152.

${ }^{26}$ Marshall, John Locke, p. 17.

${ }^{27}$ Michael Hunter, 'Aikenhead the atheist' in his Science and the Shape of Orthodoxy (Woodbridge, 1995), pp. 308-22; Michael F. Graham, The Blasphemies of Thomas Aikenhead: Boundaries of Belief on the Eve of the Enlightenment (Edinburgh, 2008).

${ }^{28}$ This has received relatively little attention in general surveys of toleration debates, though one does find a scriptural index at the end of each volume of Lecler, Toleration and the Reformation, I, p. 432; II, p. 544. See also Andrew Murphy, Conscience and Community: Revisiting Toleration and Religious Dissent in Early Modern England and America (University Park, PA: Penn State University Press, 2001), pp. 96-103.

${ }^{29}$ Eric Nelson, The Hebrew Republic: Jewish Sources and the Transformation of European Political Thought (Cambridge, MA: Harvard University Press, 2010), p. 3.

${ }^{30}$ [Roger Williams], The Bloudy Tenent of Persecution (1644), pp. 160, 179.

${ }^{31}$ [Henry Robinson], Liberty of Conscience (1644), p. 13.
} 
religion'. This had been 'urged with much vehemence to th[e]ir imitation'. ${ }^{32}$ Furly's associates operated in a more cosmopolitan and multi-confessional context than the radical Independents of the 1640s, but they too were confronted by an Old Testament case for coercion. The exiled Huguenot pastor Pierre Jurieu held firmly to the teaching of the Reformed confessions on the civil magistrate - that Christian rulers had the same coercive power in matters of religion as their Hebrew predecessors. ${ }^{33}$ When van Limborch sought to refute 'the Bloody Opinion of Hereticide', he turned first to 'several Places of the Old Testament, wherein Apostates, false Prophets, and Blasphemers are commanded to be put to Death, Deut. 13.1, \&c. Ch. 18.20. Lev. 24.16' ${ }^{34}$

At the same time, however, tolerationists needed to tackle New Testament proof texts employed by Augustine and his successors: the Parable of the Banquet; Christ's cleansing of the temple; the violent, blinding conversion of Saul on the Damascus Road; the teaching of Romans 13 about magistrates bearing a sword against evildoers; the prophecies of Revelation about the kings of the earth destroying the Beast. All of these texts had been read and applied literally to sanction the use of physical force in matters of religion. The challenge was to find another way of reading the texts, one that would nullify 'biblical violence' while preserving biblical authority.

\section{Hermeneutical Strategies}

The Protestants associated with Robinson and Furly could draw on existing sources and traditions that suggested effective hermeneutical strategies for countering the Augustinian defence of religious coercion. From Josephus and rabbinic commentaries, learned Hebraists had constructed an Old Testament argument for toleration. On the radical wing of the Reformation, Anabaptists and other sectarian Protestants had accentuated the gulf between the dispensation of the Old Testament and that of the New. And the natural law tradition offered control principles that could be used to govern biblical reading. We will consider each in turn - the Hebraic, dispensational, and natural law arguments. ${ }^{35}$

Having inspired the Jews, it could be read in favor of the Palestinians.

The Hebraic Argument

\footnotetext{
${ }^{32}$ Milton, A Treatise of Civil Power (1659), in The Complete Prose Works of John Milton, ed. Dom Wolfe, 8 vols (New Haven: Yale University Press, 1953-82), VII, p. 259.

${ }^{33}$ On Jurieu's reliance on the Old Testament see Walter Rex, Essays on Pierre Bayle and Religious Controversy (The Hague: Martinus Nijhoff, 1965), ch. 6. For a more general survey of Jurieu's intolerance see Marshall, John Locke, ch. 14.

${ }^{34}$ Van Limborch, A Compleat System, p. 987.

${ }^{35}$ On the use and rejection of Old Testament precedent in English debates on church and state, see also Eliane Glaser, Judaism without Jews: Philosemitism and Christian Polemic in Early Modern England (Basingstoke: Palgrave MacMillan, 2007), esp. ch. 4; and Acsah Guibbory, Christian Identity, Jews and Israel in SeventeenthCentury England (Oxford: Oxford University Press, 2010).
} 
The Hebraic case for toleration has long remained hidden from view, but it has recently been brought to light thanks to the labour of scholars like Eric Nelson and Jason Rosenblatt. ${ }^{36}$ They have shown us how the leading Protestant Hebraists of the first half of the seventeenth century, Hugo Grotius and John Selden, used rabbinic sources to argue against clericalism and religious persecution. As firm Erastians, these writers were concerned to unify church and state under the authority of the magistrate, and to secure a degree of toleration at the same time. They drew inspiration from the writings of Josephus, who argued that in the Hebrew theocracy there was only one source of law (the civil sovereign), only one jurisdiction (the civil magistrate), and only one rationale for religious law (a civic rationale). In the hands of Erastian tolerationists, this approach robbed the church of any independent power of excommunication, and placed sovereignty exclusively in the hands of civil magistrates, who would only legislate on religion for civic reasons. The strict application of that criterion, argues Nelson, meant that 'the set of religious matters deemed worthy of civil legislation grew steadily smaller - until at last it was virtually empty' ${ }^{37}$

Of course, holding up the Hebrew republic as a model could easily backfire, playing into the hands of Reformed divines who cited Mosaic texts to justify capital punishment for heresy. But Selden had a simple retort. In one vital respect, the Hebrew republic was utterly unique it was a pure theocracy with God as its civil sovereign. For that reason, idolatry and blasphemy in Israel were literally treasonous, and so subject to capital punishment. In states where God was not the sovereign, by contrast, things were quite different. Even in theocratic Israel, according to rabbinic sources, death sentences could only be applied if a blasphemer profaned God's name in public with deliberate intent before witnesses, and despite being warned against it. As for foreigners, they were only subject to the minimalist requirements of the seven laws given to Noah as enumerated by the rabbis. In non-theocratic modern states, it was this minimalism of the Hebrew republic that was to be imitated. As Rosenblatt explains, Selden used rabbinic sources to temper 'scriptural severity'. ${ }^{38}$

Tolerationist writers in the English Revolution were aware of this gloss on the Hebrew republic. Milton's Areopagitica praised Selden as 'the chief of learned men reputed in the land', though he relied on rabbinic scholarship to shore up his case for divorce and republicanism rather than his position on religious liberty. ${ }^{39}$ Other radical Independents noted that ancient Judaism provided room for toleration. Walwyn and Robinson pointed out that the Jews of Christ's day accommodated a wide degree of doctrinal diversity, including the Sadducees who denied the resurrection of the dead. ${ }^{40}$ Henry Stubbe, who defended the 'Good Old Cause' alongside Milton in 1659, also observed that Judaism tolerated a range of sects

\footnotetext{
${ }^{36}$ Jason Rosenblatt, Renaissance England's Chief Rabbi: John Selden (Oxford: Oxford University Press, 2006), chs. 6-9; Nelson, The Hebrew Republic, ch. 3; 'From Selden to Mendelssohn: Hebraism and religious freedom', in Quentin Skinner and Martin van Gelderen (eds), Freedom and the Construction of Europe, 2 vols (Cambridge: Cambridge University Press, 2013), ch. 6.

${ }^{37}$ Nelson, The Hebrew Republic, p. 91.

${ }^{38}$ Rosenblatt, Renaissance England's Chief Rabbi, pp. 176-81. The arguments are expounded in chs. 6-8 and in Nelson, The Hebrew Republic, ch. 3.

${ }^{39}$ Milton, Areopagitica (1644), in Complete Prose Works, II, p. 513.

${ }^{40}$ The Writings of William Walwyn, ed. Jack R. McMichael and Barbara Taft (Athens, GA: University of Georgia Press, 1989), pp. 128-29, 136, 240; [Robinson], John the Baptist, p. 81;
} 
and heresies, including Pharisees, Sadducees and Essenes. And he cited Selden to show that Old Testament Israel had tolerated idolatry beyond its borders, even after neighbouring nations were conquered, and that foreigners within Israel were only required to observe 'the seven precepts of Noah'. He provided examples of the Hebrews' tolerance of idolaters: Abraham coexisted with them, Jacob married Laban's daughter ('an Idolatresse'), Solomon displayed generous hospitality to the Queen of Sheba. ${ }^{41}$

John Locke (who had been a fellow student with Stubbe at Christ Church, Oxford) agreed that the Hebrew republic practiced broad toleration. Although Israel took many foreign captives, he noted, 'we find not one man forced into the Jewish Religion, and the Worship of the True God, and punished for Idolatry, though all of them were certainly guilty of it'. While Jews who committed idolatry were subject to the death penalty, this was because God was 'the King of the Jews', and idolatry was 'an Act of High-treason', a 'manifest revolt' against his rule. In other states, where God was not the civil sovereign, false religion was not treason, and the magistrate could only enforce matters that touched directly on 'Civil

Concernments'. ${ }^{42}$ Pierre Bayle dealt with the Mosaic law in the same manner. Because Israel was a theocracy, and God was the 'supreme and temporal Lord of the Jewish

Commonwealth', idolatry and blasphemy constituted 'an overt Act of High Treason', an 'Attempt of Rebellion against the Sovereign Magistrate'. Because idolaters and blasphemers were committing 'Treason and Rebellion against the State', their crime became 'punishable by the Secular Arm'. But 'Christians are under no Theocratical Form of Government', and such considerations did not apply. Instead, 'Convertists' who used coercion on so-called 'Hereticks' should learn a lesson from the Jews. The Jews might have punished those who 'renounced the true God' to worship idols, but they 'tolerated the most detestable Heresys', including that of the Sadducees. ${ }^{43}$

The Hebraic argument employed by these writers involved a selective appropriation of the Jewish republic. It managed to invoke the Mosaic model and neutralise it at the same time. The Hebrew republic was invoked to undermine independent clerical power, place undivided jurisdiction in the hands of the civil magistrate and secure a wide degree of toleration for religious opinion. It was neutralised insofar as the Mosaic penal laws against idolatry and blasphemy were confined to the unique theocracy of the Jews. Nelson shows how this line of argument was taken up by Hobbes, Harrington and Locke, and he suggests that Hebraic Erastianism was 'the most important and influential tradition of early-modern tolerationist thought'. ${ }^{44}$ But for most of the writers in the Robinson or Furly circles, it was arguably of less value than a second line of scriptural reasoning. However much they admired Grotius and Selden, Milton and Locke developed a very different account of the relationship between church and state - one that looked to the New Testament rather than the Old. To understand why, we need to turn to what I shall call the dispensational argument.

\footnotetext{
${ }^{41}$ Henry Stubbe, An Essay in Defence of the Good Old Cause (1659), sig. **6, pp. 42-59, 101-20.

${ }^{42}$ Locke, A Letter concerning Toleration, pp. 36-39, 6.

${ }^{43}$ Bayle, A Philosophical Commentary, pp. 179-80, 183.

${ }^{44}$ Nelson, The Hebrew Republic, p. 89.
} 


\section{The Dispensational Argument}

In contrast to the Hebraic argument, this argument focussed on the perils of judaizing. ${ }^{45}$ It drove a firm wedge between what Milton called God's 'two great dispensations, the law and the gospel', contrasting the coercion of Old Testament Israel and the non-violence of the New Testament Church. ${ }^{46}$ This line of reasoning emerged from the radical wing of the Reformation, and it is no coincidence that its leading exponent in the 1640s was a former Baptist, Roger Williams. The so-called 'Anabaptists' had always resisted the analogy between Old Testament circumcision and New Testament baptism. He began his Bloudy Tenent of Persecution with a set of propositions, the most startling of which was cited on numerous occasions by outraged critics:

Sixth, it is the will and command of God that (since the coming of his Son the Lord Jesus), a permission of the most Paganish, Jewish, Turkish, or Antichristian consciences and worships be granted to all men in all Nations and Countries, and that they are only to be fought against with that sword which is only (in Soule matters) able to conquer, the Sword of God's Spirit, the Word of God. ${ }^{47}$

The critical phrase here was 'since the coming of his Son the Lord Jesus'. According to Williams, Calvin, Beza and John Cotton were correct to claim that during the age of Israel, religious coercion had been divinely sanctioned. But this power had been abrogated by the coming of Christ. In the Church age, the true faith could only be propagated by spiritual means.

Williams’ next proposition clarified and extended the argument:

Seventh, the state of the Land of Israel, the Kings and people thereof in Peace and War, is proved figurative and ceremonial, and no patterne nor president for any Kingdom or civill state in the world to follow. ${ }^{48}$

Here Williams was exploiting typology. He was able to do so because its use was entirely conventional among Protestants, a fact easily overlooked if we take Reformation literalism too literally. ${ }^{49}$ Typology had its roots in early Christian readings of the Old Testament, particularly in the Book of Hebrews, which saw the 'types' of the tabernacle fulfilled in Christ. This Christological typology had been elaborated with great sophistication and imagination by Origen. But after the conversion of Constantine, Eusebius of Caesarea employed typology for a different purpose, portraying the Christian emperor as a new Moses.

\footnotetext{
${ }^{45}$ Here I agree with Robert Yelle, who has argued (with reference to Roger Williams and others) that 'Nelson underestimates the role that traditional Christian anti-Judaism, particularly as expressed in biblical typology, played in a broader process of secularization'. See Yelle, 'Moses' Veil: Secularization as Christian Myth', in Winnifred Sullivan, Robert Yelle and Mateo Taussig-Rubbo (eds), Cultural Lives of Law: After Secular Law (Palo Alto, CA: Stanford Law Books, 2011), ch. 1, quotation at p. 31.

${ }^{46}$ Complete Prose Works of John Milton, VII, p. 281.

${ }^{47}$ Williams, The Bloudy Tenent, sig, a2v.

${ }^{48}$ Williams, The Bloudy Tenent, sig, a2v.

49 See Sacvan Bercovitch, 'Typology in Puritan New England: The Williams-Cotton Controversy Reassessed', American Quarterly, 19 (1967), 163-91; James P. Byrd, The Challenges of Roger Williams: Religious Liberty, Violent Persecution and the Bible (Macon, GA: Mercer University Press, 2002).
} 
English Protestants used the Old Testament in both ways, seeing Israel as fulfilled in the Church, but also claiming Protestant nations as 'new Israels'. In the Bloudy Tenent, however, Williams used 'spiritual typology' to undermine 'historical typology'. ${ }^{50}$ He devoted many pages of his book to showing 'how weake and brittle this supposed Pillar of Marble is'. The state of Israel had been 'much imitated' by 'Christian' nations, he noted; but it was 'unimitable', 'unparalleled and unmatchable'. It was not intended as a 'pattern' for modern nations or kingdoms; instead, it was a type of the Church. Since the coming of Christ, there were no national churches, and no magistrates stood in the place of the kings of Israel and Judah. The task of the magistrate was 'essentially Civill', and the Church was a purely voluntary body. Where could one find 'the least footing in all scripture for a Nationall Church after Christ's coming?' What 'president' was there under the gospel for forcing the ungodly to participate in Christian worship? ${ }^{51}$

Williams pressed this point relentlessly in his tolerationist writings of the mid-1640s and the early 1650s. Appeals to the Hebrew commonwealth were ruled out of court. The proponents of national churches and religious uniformity were required to produce proof from Christ's 'last Will and Testament' (i.e. the New Testament). To advocate an established national church on Old Testament grounds was 'a reviving of Moses', and it prompted the question: 'are you Moses or Christ's followers?' Coercive state religion was 'but one of Moses shadows, vanished at the comming of the Lord Jesus'. ${ }^{2}$

Henry Robinson pursued the same line of thought. He alleged that those whom he called 'the Reformed persecuters' could not produce a 'warrant' or 'commission' from Christ for religious coercion. ${ }^{53}$ If Christ or the Apostles had intended the church to use force against heretics in future generations, surely they would 'have left some ground or warrant inserted in the letter of the Gospel'. ${ }^{54}$ Yet one could search the New Testament in vain for any such warrant. Robinson's John the Baptist set out the textual evidence. Each chapter began with a string of New Testament texts identifying Christ and his apostle’s 'commission', 'order', 'warrant', 'instructions' and 'testimonies'. Robinson listed over 300 biblical texts, not a single one from the Old Testament. By demanding that his critics demonstrate their claims from the apostolic writings, he could load the odds against religious coercion, tithes and national churches. ${ }^{55}$

Milton too relied heavily on the argument from abrogation in his 1659 attacks on 'force' and 'hire', or coercion and tithes. Like Luther, he set up a series of Pauline dualisms between Judaism and Christianity, outward and inward, childhood and manhood, bondage and freedom. Under the Old covenant, force was necessary in religion; under the New, it was replaced by persuasion. God had once joined church and state together; now he had 'severd

\footnotetext{
${ }^{50}$ The tension between the spiritual typology of Origen and the political typology of Eusebius and its relevance to toleration debates is explored in Henning Graf Reventlow, The Authority of the Bible and the Rise of the Modern World (London: SCM, 1984), pp. 140-44, 180-81.

${ }^{51}$ Williams, The Bloudy Tenent, sig. a2v, pp. 178-79, 183-84, 195.

${ }^{52}$ Williams, Queries of the Highest Consideration (1644), pp. 1, 3, 6, 13.

53 [Robinson], John the Baptist, pp. 99, 18-19, 56-57, 70, 85-86,

54 [Robinson], Liberty of Conscience, pp. 16, 22, 28-30; [Robinson], John the Baptist, pp. 20, 85-86, 99.

55 [Robinson], Liberty of Conscience, p. 3. See also pp. 14-20; [Robinson], John the Baptist, pp. 6-7, 84-85
} 
them'. For Milton (as for Williams), the history of Christianity was a story of fall and restoration. After Constantine, error 'had miserably Judaiz'd the church', introducing 'priests, altars, and oblations', as well as persecution and tithes. ${ }^{56}$ The Reformation had initiated the process of de-judaizing and restoring primitive Christianity, but Protestantism was still plagued by judaisers. Hence Milton's warning to 'the New Forcers of Conscience' that Parliament would 'Clip your Phylacteries'. 57

The problem of Old Testament precedent looms less large in the writings of the 1680s, but it could not be ignored. Pierre Bayle tackled it in characteristically bold and original fashion. Faced with his fellow Huguenot, Pierre Jurieu, who turned to the Old Testament to justify armed resistance and religious coercion, Bayle set out to problematize appeals to the Hebrews by pointing out their faults. In the first edition of his Dictionnaire Historique et Critique (1697), he included a notoriously irreverent article on King David, indicting the Hebrew monarch for polygamy, adultery, murder and massacre. According to Walter Rex, his purpose was to turn his fellow Huguenots away from the political and religious violence of the Old Testament to the ethics of Jesus. ${ }^{58}$

Locke and van Limborch took a more conventional approach. The latter maintained that advocates of hereticide made a basic category mistake, misapplying Old Testament laws about apostates, blasphemers and false prophets to Christian heretics. But he also employed the dispensational argument: 'the Judicial Laws of Moses, so far as they concern only the Jewish Commonwealth, were abrogated upon the Destruction of that Polity, and are not obligatory to us Christians'. ${ }^{59}$ Locke went further, rejecting the traditional distinction between the ceremonial, judicial and moral elements of the Mosaic law, and insisting that the entire Law of Moses had been abrogated and 'is not obligatory to us Christians...for no positive Law whatsoever can oblige any People but those to whom it is given'. Israel only punished idolatry because it was a theocracy in which church and state were one. After Christ's birth, he continued, a new distinction was made between Church and Commonwealth - 'there is absolutely no such thing, under the Gospel, as a Christian Commonwealth'. This was a claim reminiscent of Roger Williams, who had also argued that under the New Testament, the state was purely civil, the church wholly voluntary. And like Henry Robinson, Locke insisted that defenders of coercion possessed no 'Commission' from Christ to use of the sword on behalf of the Gospel. ${ }^{60}$

The Natural Law Argument

\footnotetext{
${ }^{56}$ Complete Prose Works of John Milton, VII, pp. 239, 277, 281, 260, 290-91.

57 John Milton, Complete Shorter Poems, ed. John Carey (London: Longman, 1971), p.295. For further analysis of Milton's views on Old Testament Israel see Douglas Brooks (ed.), Milton and the Jews (Cambridge: Cambridge University Press, 2008); Guibbory, Christian Identity, Jews and Israel, esp. ch. 8.

${ }^{58}$ Rex, Essays on Pierre Bayle, ch. 6. Selections from the essay are anthologised in Bayle: Political Writings, ed. Sally Jenkinson (Cambridge University Press, 2000), pp. 36-54.

${ }^{59}$ Van Limborch, A Compleat System, p. 987.

${ }^{60}$ Locke, A Letter concerning Toleration, pp. 36-38.
} 
This appeal to Christ still left unresolved the New Testament proof texts cited by Augustine and later proponents of religious coercion. Tolerationists often dealt with these in piecemeal fashion, arguing on a case-by-case basis that the texts had been misread. Thus Milton dismissed 'that parabolical proof Luke 14. 16, \&c. compel them to come in', on the grounds that parables should be 'expounded by the general scope thereof', not by wresting phrases out of context. He dismissed the relevance of Christ's cleansing of the temple on the grounds that Christ had used whips 'to drive profane ones out of his temple, not to force them in'. As for the burning of magical books by the Christians of Ephesus, this was a voluntary destruction of their own property, not compulsory censorship by the magistrate. ${ }^{61}$

Philip van Limborch took the same exegetical approach in his systematic theology, working through the 'hereticide' proof texts one-by-one to show why they had been misapplied.

Ananias and Sapphira were struck dead by God in Acts chapter 5, but not because of heresy; besides, 'we are not to imitate what the Apostles did by a miraculous power' and following 'an express Divine Command'. Romans 13 was irrelevant because the magistrate was not granted dominion over conscience. The destruction of Antichrist by Kings in Revelation 17 was predicted not commanded; and anyhow, Antichrist was 'drunk with the Blood of the Saints', not merely mistaken on a point of doctrine. ${ }^{62}$

Pierre Bayle, by contrast, offered a different solution to the problem, providing what we shall call 'the natural law argument' against coercion. ${ }^{63}$ He wrote a Philosophical Commentary on the classic Augustinian text from Luke chapter 14: 'Compel them to come in'. His stated goal was to offer 'a Refutation of the Literal Sense of the Passage', just as others had done in the case of the Old Testament. But he would not do so by commenting on the text like 'Criticks and Divines', who compare it with other passages, examine the context, explore 'the Force of Expressions in the Original', the various senses which they might bear. Instead, he proposed to cut the Gordian knot in one stroke, by setting up a 'single Principle of natural Reason' as the Rule for 'all interpretation of Scripture'. His principle was simply stated: 'That all literal Construction, which carries an Obligation of committing Iniquity, is false'. Every interpretation, then, would be tried before 'the supreme Court of Reason and natural light'. 'By this primitive and metaphysical Light', he explained, 'we have discovered the rightful Sense of infinite Passages of Scripture, which taken in the literal and popular Meaning of the Words, had led us into the lowest Conceptions imaginable of the Deity'. ${ }^{64}$

Bayle's trial of the literal interpretation of Luke 14:23 demonstrated that it violated the 'single Principle' or Rule of God-given Reason by leading inexorably to Iniquity. In the first place, coercion violated 'Ideas of natural Light', by producing hypocritical worship rather than the sincere love, fear and reverence which the supreme being justly deserves. Second, it was 'contrary to the whole tenor and Spirit of the Gospel', which had itself been 'verified' by

\footnotetext{
${ }^{61}$ Complete Prose Works of John Milton, VII, pp. 260-61, 268; II, p. 514.

${ }^{62}$ Van Limborch, A Compleat System, pp. 988-91.

${ }^{63}$ On Bayle's use of natural theology see lan Harris, 'Toleration and its place: A study of Pierre Bayle in his Commentaire Philosophique', in Sarah Hutton and Paul Schurman (eds), Studies on Locke: Sources, Contemporaries, and Legacy (Dordrecht: Springer, 2008), pp. 225-43.

${ }^{64}$ Bayle, A Philosophical Commentary, pp. 65-69.
} 
the 'Original Rule' of 'natural light'. Third, it confounded Virtue and Vice, and so 'overturns all Morality’. Fourth, it gave Infidels 'a very plausible’ pretence for persecuting Christians. Fifth, it could not be put into practice 'without unavoidable Crimes'. Sixth, it removed one of the main Christian objections to Islam, i.e. that it was 'built upon persecuting Principles'. Seventh, it was unknown to the Fathers of the first three centuries. Eighth, it undermined 'the Complaints of the first Christians against their Pagan Persecutors'. Finally, it exposed 'true Christians to continual Violences' and turned the world into 'a continual Scene of Blood'. ${ }^{65}$ In short, the literal interpretation carried 'an Obligation of committing Iniquity', and was therefore false. Logically, Christians were required to adopt a 'metaphorical' reading of the passage. Christ's 'compel' must refer to the moral force of compelling preaching, not to physical force. ${ }^{66}$

Bayle's natural law argument was open to the criticism that it had set an external authority Reason - over and against Scripture. But the Philosophical Commentary sought to forestall such objections. Firstly, Bayle alleged that 'the whole Body of Divines, of what Party soever, after having cry'd up Revelation...come to pay their homage at last at the Footstool of the Throne of Reason'. Protestants would never concede the Socinian claim that the Trinity or Incarnation are 'contradictory doctrines'. Catholics fiercely denied that Transubstantiation was 'repugnant to sound Philosophy'. Hence all theologians acknowledged that divine Revelation must correlate with God-given Reason. ${ }^{67}$ Secondly, Bayle stressed that 'natural Light' came from God. Citing the Prologue of John's Gospel, he called it 'the light which enlightens every man'. The Scriptures themselves testified to this 'natural Revelation', 'this primitive and metaphysical Light'; hence it was only right and proper that the special revelation of the Bible lined up with the natural revelation of Reason. ${ }^{68}$ The evident principles of natural light could trump debateable interpretations of Scripture, but this did not mean that the clear teaching of the Bible could be undercut by questionable maxims of reason. ${ }^{69}$

Yet in seeking a principle or rule to govern the interpretation of 'infinite passages of Scripture', in the New Testament as well as the Old, Bayle went beyond traditional Reformed theology. Although the concept of 'natural light' had a place within Reformed orthodoxy, Bayle (perhaps unintentionally) reinforced the growing tendency to prioritise natural over revealed theology. ${ }^{70}$ He also went beyond earlier tolerationists. They had sometimes argued that the magistrate could only punish teaching or practice which violated 'natural light'. Thus it was criminal to deny the existence of God or future judgment, since these were allegedly

\footnotetext{
${ }^{65}$ This chapter summarises the arguments Bayle, A Philosophical Commentary, Part I, chs. 2-10. See pp. 8-11.

${ }^{66}$ Bayle, A Philosophical Commentary, pp. 66, 78.

${ }^{67}$ Bayle, A Philosophical Commentary, pp. 66-68.

${ }^{68}$ Bayle, A Philosophical Commentary, pp. 68-75.

${ }^{69}$ See John Kilcullen, Sincerity and Truth: Essays on Arnauld, Bayle, and Toleration (Oxford: Clarendon Press, 1988), p. 103. One could draw an analogy with debates over science and Scripture. A Baylean approach would suggest that firmly established scientific findings (e.g. heliocentrism or biological evolution) should trump debatable interpretations of the Bible (e.g. literalist readings of Joshua's long day or the six-day creation account in Genesis 1-2).

${ }^{70}$ See Richard Muller, Post-Reformation Reformed Dogmatics, 4 vols (Grand Rapids: Baker, 2003), I, ch. 6:

'Natural and Supernatural Theology', esp. p. 307.
} 
accessible to natural reason, while it was not criminal to deny the Trinity or even the Scriptures, since these doctrines were the product of special revelation. ${ }^{71}$ But rather than using the idea of 'natural light' to demarcate the boundaries of toleration, Bayle used it to regulate biblical interpretation, apparently elevating it above Scripture. Indeed, many readers in his lifetime and later detected in his writings irreverence and scepticism towards the Bible - not least in the biblical articles of his famous Dictionary. His Philosophical Commentary fed the Enlightenment assumption that Scripture was ethically superfluous, since its moral teachings were more accessible by the light of nature. For this reason, it arguably marked the close of 'the biblical century' in political thought.

Despite the differences between Bayle and other Protestant tolerationists, they had all tried to establish hermeneutical frameworks that would explain which texts should be read literally and which should not, which texts were binding and which had been abrogated. Christian Hebraists had used rabbinic sources to distinguish between what was living in the Hebrew republic (its Erastianism and toleration) and what was dead (its theocratic penal laws). Radical Protestants had applied the dispensational argument in order to show that the state and land of Israel was a type of Christ, fulfilled at his coming, and thus no 'pattern nor precedent' under the Gospel. These approaches arguably pointed towards different religious settlements - Selden's Hebraic argument foreshadowed England's tolerant, Erastian church establishment after 1689, while the Miltonic case for severing church and state would find its fulfilment in the disestablishment of America's First Amendment in 1791. But both strategies (like Bayle's 'light of nature' hermeneutic) had successfully tamed or neutralised some of the Bible’s fiercest texts. By reinterpreting Scripture, tolerationists had re-imagined Christendom.

\section{Scripture and Toleration in Contemporary Islam}

This point is not lost on contemporary reformers within the Islamic tradition. Writing in the Guardian, the former Islamist Ed Husain praises a 600-page Pakistani fatwa condemning suicide bombing and terrorism as unscriptural. He defends the value of such theological interventions by comparing them to John Locke’s works on tolerance. These were, he explains, 'Christian fatwas in the midst of 17th century European wars of religion. Locke wrote with references to the Bible. His arguments were rooted in theology'. ${ }^{72}$ Other Muslim commentators are equally struck by the parallels between Locke and today's liberal Muslim intellectuals. One recent writer is impressed by how many of these Islamic reformers have shared Locke's experience of exile. Like him, they operate in a context of great political turmoil and clerical authoritarianism. And like him, they construct religious arguments against intolerance. 'Muslims', the article concludes, 'can learn more about how to argue for toleration by studying him'. Because Locke speaks the language of belief, conscience and

\footnotetext{
${ }^{71}$ See the arguments of radical Independents like John Goodwin and John Wildman in 'The Whitehall Debates, December 1648', in A.S.P. Woodhouse (ed.), Puritanism and Liberty: Being the Army Debates (1647-49) From the Clarke Manuscripts (London: J.M. Dent, 1992), pp. 156-57, 161. Reventlow, The Authority of the Bible, pp. 180-81, suggests that despite the Puritan appeal to the Bible, 'the decisive criteria comes from other spheres', not least from natural law.

${ }^{72}$ Ed Husain, 'Fatwas can be a Force for Good', The Guardian, 26 February 2010.
} 
true religion, he is 'more accessible' to Muslim audiences than philosophers who talk of 'secularism'. ${ }^{73}$

A similar case is made by Nader Hashemi in his acclaimed book Islam, Secularism and Liberal Democracy, which includes a chapter entitled 'Duelling Scriptures: The Political Theology of John Locke and the Democratization of Muslim Societies'. If Muslims want to use 'comparative historical analysis' to understand their own societies, he argues, they should look to the English Revolution rather than the French, and to the era when political thought involved political theology. Indeed, Hashemi finds striking 'political and religious parallels between Locke's England' and twenty-first century Iran. Locke is significant because he reveals 'the religious roots of modern liberal democracy', and shows 'how it is possible to find theoretical space within religion to advance an argument for popular sovereignty and human rights'. Like contemporary reformers, he proceeded by 'a reinterpretation - not outright rejection - of religious thought', and was thus able to 'advocate a new political philosophy without alienating his entire political constituency'. He is relevant because his arguments for toleration emerge 'out of a dissenting religious exegesis'. Faced with the authoritarians of the Islamic world, reformers can imitate Locke. $^{74}$

Academic historians tend to be suspicious of such instrumentalist appropriations of the past. We warn against 'presentism' and the risk of anachronism, and wince at misleading analogies between past and present. Instead of seeking a usable past, we stress that the past is a foreign country, a place for trained historians, somewhere that politicians and public moralists would be best to avoid. We even say that the past should be studied for its own sake (whatever that means). Historians have been quick to highlight the limits of Miltonic or Lockean tolerance, their distance from modern secular liberalism.

Yet whether we like it or not, the seventeenth-century thinkers we have discussed are being keenly considered in contemporary debates over religion, coexistence and toleration. When the philosopher Martha Nussbaum excavates America’s tradition of religious equality, she pays particular attention to Roger Williams. ${ }^{75}$ In the wake of 9/11, discussion among literary intellectuals centres on the 'biblical violence' or the 'religious terrorism' of Milton's Samson. ${ }^{76}$ When Mark Lilla attempts to explain 'the Great Separation’ between religion and politics in the West, he draws a genealogy originating from Hobbes and Locke. ${ }^{77}$ When

\footnotetext{
73 Joy Samad, John Locke and Muslim Liberalism', Journal of Church and State, 53 (2010), 84-108.

${ }^{74}$ Nader Hashemi, Islam, Secularism and Liberal Democracy: Towards a Democratic Theory for Muslim Societies (Oxford: Oxford University Press, 2009), ch. 2, quotations at pp. 17-18, 100-02. The case for drawing on the English rather than the French Revolution is made in chapters 1 and 3.

${ }^{75}$ Martha Nussbaum, Liberty of Conscience: In Defense of America's Tradition of Religious Equality (New York: 2008).

${ }^{76}$ John Carey, 'A Work in Praise of Terrorism? September 11 and Samson Agonistes', Times Literary Supplement, 6 September 2002, pp. 15-16.

${ }^{77}$ Mark Lilla, The Stillborn God: Religion, Politics and the Modern West (New York: Random House, 2007). See the extensive online engagements at The Immanent Frame: http://blogs.ssrc.org/tif/category/the-stillborngod/ (accessed 1.10.2012).
} 
secularists man the ramparts to defend the Enlightenment, they are increasingly likely to hail Bayle and Spinoza. ${ }^{78}$

These retrospective glances reflect a sense of cultural déjà vu, a perception that twenty-first century societies are reliving early modern crises. Even among Protestants, there are some who look back with nostalgia to the pre-Enlightenment when heretics and blasphemers received their just deserts. On the fringe of the American Religious Right, a group variously known as Theonomists, Dominionists or Christian Reconstructionists argue that the Mosaic penal laws (including capital punishment for blasphemy) should still apply in Christian states. In conservative Presbyterian circles, the Theonomists and their critics replay the debates of the 1640s. ${ }^{79}$ Yet despite being Exhibit A in almost every alarmist tract written against the Religious Right, the Theonomists' flat repudiation of modern ideals of religious liberty is radically out of step with Protestant opinion since the Enlightenment. Very few contemporary Protestants (whether liberal or conservative), and very few Catholics (whether modernist or traditionalist) would have any quarrel with Article 18 of the UN's Universal Declaration of Human Rights (1948):

Everyone has the right to freedom of thought, conscience and religion; this right includes freedom to change his religion or belief, and freedom, either alone or in community with others and in public and private, to manifest his religion or belief in teaching, practice, worship and observance. ${ }^{80}$

Within twenty-first century Islam, however, this modern doctrine of religious liberty is still deeply controversial. In the Cairo Declaration on Human Rights in Islam, the Organization of the Islamic Conference adopted a very different position in Article 10: 'Islam...prohibits any form of compulsion on Man or the exploitation of his poverty or ignorance in order to convert him to another religion or to atheism'. ${ }^{81}$ Whereas the UN's Declaration guarantees what political philosophers call 'exit rights', the OIC's is designed to rule out any missionary intrusion from either Christians or secularists. Behind this clause lies the double standard that once prevailed among Protestants and within Roman Catholicism before Vatican II - freedom for the true religion does not entail freedom for false religion. In the case of Islam, that double standard is underpinned by the traditional law against apostasy. As one liberal Muslim puts it, 'The implication is that Islam is a religion with free entry, but no free exit' ${ }^{82}$

The debate over whether apostasy should be a capital offence divides some of the most famous names within modern Islam. On the one side, defending the death penalty (at least for apostates who insist on proselytising others), stand leaders like the celebrated Egyptian cleric

\footnotetext{
${ }^{78}$ See for example, Christopher Hitchens, God is Not Great: The Case against Religion (London: Atlantic Books, 2007), pp. 260-64.

${ }^{79}$ See William S. Barker and W. Robert Godfrey (eds), Theonomy: A Reformed Critique (Grand Rapids: Zondervan, 1991), which revisits the arguments of Westminster Assembly divines.

${ }^{80}$ http://www.un.org/en/documents/udhr/index.shtml (accessed 3 October 2012).

${ }^{81}$ Cited in Adbullah Saeed and Hassan Saeed, Freedom of Religion, Apostasy and Islam (Aldershot: Ashgate, 2004), pp. 16-17.

${ }^{82}$ Mustafa Akyol, Islam without Extremes: A Muslim Case for Liberty (New York: W.W. Norton, 2011), p. 274. See more generally, ch. 15: 'Freedom from Islam'.
} 
Yusuf al-Qaradawi. ${ }^{83}$ On the other side, opposing capital punishment for apostasy, are reformists like the Swiss intellectual Tariq Ramadan, a figure variously touted as a 'Muslim Martin Luther' or a 'Muslim John Locke'. ${ }^{84}$ While the numbers of people actually executed for apostasy in the Islamic world are tiny (as were the number of heresy executions in seventeenth-century Protestant Europe), there are good reasons for thinking that apostasy and blasphemy codes have a chilling effect on freedom of expression. ${ }^{85}$

The contemporary intra-Islamic debate over apostasy bears comparison with the postReformation intra-Protestant controversy over the civil punishment of heretics and blasphemers. Of course, there are many differences, not least in the contents of sacred texts the conception of scripture and authority, and the historical contexts. The early modern Protestant controversy occurred in a world without liberal democracies or universal declarations of human rights, and played a part in creating that world. Whereas the Christian debate focussed on capital punishment for 'heretics', the Islamic debate is centred on the concept of riddah (usually translated as 'apostasy'), a quite different category. ${ }^{86}$ Yet in both cases, the advocates of repression make a scriptural case, one their critics simply have to address. Moses or Muhammad have to be contextualised. While this could be done by flatly denying the authority of sacred texts, this is hardly likely to win over a religious community. Change is more likely to be effected by thinkers working from within the tradition who persuasively reinterpret scriptural texts, and reform scriptural reading.

This is the project undertaken by Muslim critics of blasphemy and apostasy laws, like the former Chief Justice of Pakistan, S.A. Rahman, or the professor of Islamic Studies, Abdullah Saeed. ${ }^{87}$ Where seventeenth-century Protestants had to undermine the scriptural case for coercion made by St Augustine and endorsed by the Reformers, modern Muslims have to counteract the sheer weight of Islamic tradition that lies behind the death penalty for apostasy. As Tariq Ramadan explains, 'The great majority of the Muslim scholars, from all the different traditions and throughout history, have been of the opinion that changing one's religion is prohibited in Islam and should be sanctioned by the death penalty' ${ }^{88}$ The major

\footnotetext{
${ }^{83}$ See Yusuf Al-Qaradawi, 'Apostasy: Major and Minor' (2006) at http://islam.maxforum.org/2010/04/03/apostasy-major-minor/ (accessed 5.10.2012).

${ }^{84}$ Paul Donnelly, 'Tariq Ramadan: The Muslim Martin Luther?', Salon, 15 Feb 2002:

http://www.salon.com/2002/02/15/ramadan_2/; Andrew F. March, 'Reading Tariq Ramadan: Political Liberalism, Islam and "Overlapping Consensus", Ethics and International Affairs, 21 (2007):

http://www.carnegiecouncil.org/publications/journal/21_4/essays/001.html (accessed 5.10.2012). Ramadan himself cites Locke and Voltaire on tolerance in The Quest for Meaning: Developing a Philosophy of Pluralism (London: Allen Lane, 2010), ch. 4.

${ }^{85}$ See Paul Marshall and Nina Shea (eds), Silenced: How Apostasy and Blasphemy Codes are Choking Freedom Worldwide (New York: Oxford University Press, 2012).

${ }^{86}$ For the complex relationship between concepts of apostasy, blasphemy and heresy in Islam see K. Hashemi, Studies in Religion, Secular Beliefs and Human Rights: Religious Legal Traditions, International Human Rights Law and Muslim States (Leiden: Martinus Nijhoff, 2008), pp. 21-131.

${ }^{87}$ S.A. Rahman, Punishment of Apostasy in Islam ([1972]; New Delhi: Kitab Bhaban, 1996); Saeed and Saeed, Freedom of Religion, Apostasy and Islam.

88 'Muslim scholars speak out on jihad, apostasy and women' (28 July 2007), at http://www.tariqramadan.com/spip.php?article1163\&lang=fr (accessed 3 October 2012). S.A. Rahman, Punishment of Apostasy in Islam, admits he is going against 'the generally accepted orthodox view that a change of faith by a Muslim invites the penalty of death' (p. 134). Adbullah Saeed and Hassan Saeed, Freedom
} 
schools of Islamic jurisprudence, both Sunni and Shi'a, concur that apostasy is a capital crime under sharia law, at least in the case of unrepentant adult males. The basis for this provision is found in the hadith, the collections of traditions about the Prophet which (to varying degrees) have been accorded the status of Scripture alongside the Qur'an itself. Of prime importance is the report that Muhammad said, 'Whoever changes his religion shall be put to death' ${ }^{89}$

Against this venerable tradition, modern and liberal Muslims make a number of hermeneutical moves that recall the strategies of Protestant tolerationists. ${ }^{90}$ In the first place, they appeal to the Qur'an over the hadith in much the same way that radical Protestants appealed to the New Testament over the Old. And they exploit the fact that while the Qur'an has the status of the word of God directly revealed to the Prophet, this is not the case with the hadith, which have been retold by contemporaries (some more reliably than others). The Qur'an, they argue, warns apostates of punishment in the afterlife, but prescribes no temporal punishment. Moreover, it teaches that Islam is spread through voluntary conversion not coercion. The proof text 'There is no compulsion in religion', is held up as a universal principle, just as tolerationists used the New Testament statement that 'the weapons of our warfare are not carnal, but spiritual'. For Rahman, the Qur'anic text presents 'a charter of freedom of conscience unparalleled in the religious annals of mankind' ${ }^{91}$

Traditional jurists limited or nullified this text, not least by suggesting that it had been abrogated by the Prophet's later teaching and practice as recorded in the hadith. For this reason, and in contrast to seventeenth-century Protestants, Muslim opponents of religious coercion challenge the zealous use of the principle of abrogation. Indeed, they seek to overturn the 'master narrative' whereby the tolerant texts of the Prophet's Meccan period are said to have been abrogated by the belligerent sayings and actions of his later rule in Medina. ${ }^{92}$ Reformists explain the problematic hadith in various ways, sometimes by questioning their authenticity, but primarily by placing them in the context of military struggle between the Prophet and his enemies. The 'apostates' in question, they maintain, were guilty of treason and armed rebellion, and were not punished simply for rejecting Islam. Traditionalists, by contrast, seem to depict the early Islamic community as a theocracy, much as Hebraists depicted Old Testament Israel - if God is the ruler, then apostasy from Islam or the renunciation of the God of Israel constitutes 'high treason' and 'manifest revolt' and is worthy of death. Nevertheless, Protestant tolerationists and Muslim reformists get to similar

\footnotetext{
of Religion, Apostasy and Islam, note that 'The vast majority of Muslim scholars writing on the issue of apostasy today follow the pre-modern position' (p. 88), and add that 'since there was unanimous agreement on the punishment of apostasy among pre-modern jurists, it would be very difficult for a modern scholar to oppose such a position in Islamic law' (p. 92).

${ }^{89}$ See Saeed and Saeed, Freedom of Religion, Apostasy and Islam, ch. 4; Rahman, Punishment of Apostasy in Islam, chs. 2-4.

${ }^{90}$ What follows is a brief summary of the arguments found in Rahman, Punishment of Apostasy in Islam, chs. 12; and Saeed and Saeed, Freedom of Religion, Apostasy and Islam, ch. 5. See also the numerous testimonies by moderate Muslim scholars, jurists and political leaders assembled at http://apostasyandislam.blogspot.co.uk/ ${ }^{91}$ Rahman, Punishment of Apostasy in Islam, p. 16.

${ }^{92}$ For a challenge to this 'master narrative', see Sohail H. Hashemi, 'The Qur'an and tolerance: an interpretive essay on Verse 5:48', Journal of Human Rights, 2 (2003), 81-103.
} 
conclusions by different routes - the actions of armed prophets (whether Moses or Muhammad) do not oblige modern states to execute people guilty of purely religious offenses.

If these debates have centred on the Founders of the respective faiths, they have not ended there, for reformers have had to grapple with subsequent interpretive tradition. Christian tolerationists capitalised on the fact that Christianity emerged and spread as a persecuted minority, and they were able to appeal with William Penn to 'the true Christians, of the first three Hundred Years'. ${ }^{93}$ The early Church Fathers could be played off against medieval and early modern defenders of religious coercion; even the later Augustine could be undermined by invoking his younger and better self. Tolerationists claimed the mantle of 'Primitive Christianity', and blamed the practice of religious coercion on medieval 'popish' declension. Their Muslim counterparts face a more challenging task, since the early jurists were overwhelmingly in favour of capital punishment for apostasy. In comparison to radical Protestant primitivists, Muslim (and Catholic) reformers have been less willing to write off centuries of tradition. But after contextualising draconian codes and pointing to evidence that so-called apostates were actually guilty of sedition or rebellion, they do suggest that apostasy laws were a regrettable development, a departure from the tolerant spirit of the Qur'an. ${ }^{94}$ At the same time, they can point to the minority report of some early Islamic jurists and pile up testimonies as they seek to demonstrate that their own reading of Scripture has ample support among contemporary divines, scholars and statesmen. In this respect too, they resemble Protestant tolerationists. $^{95}$

Now, as then, the battle over toleration is an intellectual struggle, a battle for sacred texts. We should not assume - Whiggishly - that the outcome is inevitable or that Islam is bound to follow a Western Christian trajectory. Even if it does, we may expect the debate to be protracted. For religious believers, ancient scripture, historic tradition and communal consensus carry much greater weight than they do for modern secular liberals. Traditional interpretations are innocent until proven guilty. Presbyterians, who had once condemned religious toleration as a 'wicked doctrine' eventually came to embrace the principle of religious liberty, but only after decades of political turmoil and intellectual change. Even then the outcome varied according to national context, and in some circles it is still controversial, as indicated by American theonomists. ${ }^{96}$ In the case of the Roman Catholic Church, the process took even longer, and Catholics are still debating whether Vatican II's Declaration on Religious Liberty (Dignitas Humanae) was a break with tradition, or merely a development

\footnotetext{
${ }^{93}$ The Political Writing of William Penn, ed. Andrew R. Murphy (Indianapolis: Liberty Fund, 2002), p. 89.

${ }^{94}$ See especially Rahman, Punishment of Apostasy in Islam,

${ }^{95}$ See Rahman, Punishment of Apostasy in Islam, passim; and Saeed and Saeed, Freedom of Religion, Apostasy and Islam, pp. 90-98; http://apostasyandislam.blogspot.co.uk/ (accessed 3 September 2012). Compare with The Political Writings of William Penn, pp. 105-11.

${ }^{96}$ For an assessment of how Presbyterians initially came to terms with broad conceptions of religious liberty see John Coffey, 'Between Reformation and Enlightenment: Presbyterian Clergy, Religious Liberty and Intellectual Change', in R. Armstrong and T. O'Hannrachain, eds, Insular Christianity: Alternative Models of the Church in Britain and Ireland, c.1550-c.1750 (Manchester University Press), 252-71.
} 
of it. ${ }^{97}$ Muslims work with a different set of sacred texts, with different concepts, and with different notions of scripture, tradition and authority, and they find themselves in an extraordinarily diverse set of cultural and geographical locations. But in the twenty-first century, as in the seventeenth, the prospects for religious toleration depend (if only in part) on scriptural hermeneutics.

\footnotetext{
${ }^{97}$ Perreau-Saussine, Catholicism and Democracy; John McGreevy, Catholicism and American Freedom: $A$ History (New York: W.W. Norton, 2003), ch. 7; Kevin Grasso and Robert P. Hunt (eds), Catholicism and Religious Liberty: Contemporary Reflections on Vatican II's Declaration on Religious Liberty (Lanham, MD: Rowman and Littlefield, 2006); Arnold T. Guminski and Brian W. Harrison, O.S., Religious Freedom: Did Vatican II Contradict Traditional Catholic Doctrine (South Bend, IN: St Augustine's Press, 2012).
} 